\title{
Effect of sweet potato flour of two local varieties on quality of breads
}

\author{
M. S. Kamal", M. N. Islam and M. G. Aziz \\ Department of Food Technology and Rural Industries, Bangladesh Agricultural University, Mymensingh-2202, \\ Bangladesh, *Email: msk.mirza@gmail.com
}

\begin{abstract}
The study was carried out in order to find out the effect of substitution of wheat flour with sweet potato flour of two local varieties (Local Sada and Local Lal) on the quality of bread. This study was also concerned with the analysis of proximate compositions of sweet potato and results showed that, fresh local sada and local lal sweet potato varieties contained moisture 70.10 and $66.78 \%$; ash 4.46 and $4.21 \%$; fat 0.71 and $0.74 \%$; protein 1.75 and $1.63 \%$; carbohydrate 22.98 and $26.64 \%$; vitamin-C 8.86 and $9.49 \mathrm{mg} / 100 \mathrm{~g}$ respectively. The compositions of sweet potato flour were also analyzed and showed that local sada and local lal sweet potato flour contained moisture 5.25 and 5.32\%; ash 4.12 and $4.17 \%$; fat 0.75 and $0.81 \%$; protein 9.80 and $9.21 \%$; carbohydrate 80.08 and $80.49 \%$; vitamin-C 2.45 and $2.31 \mathrm{mg} / 100 \mathrm{~g}$ respectively. This analysis showed that the sweet potato flour is quite rich in protein content. The breads containing of sweet potato flour were prepared using standard formulation with 5,10 or $15 \%$ substitution of wheat flour by sweet potato flour and evaluated their acceptability by a number of panelists. The result obtained showed that the color, taste, texture, flavor and overall acceptability of the breads containing sweet potato flour were equally acceptable with control bread. Statistical analysis showed that the overall acceptability of bread with sweet potato flour was equally acceptable as the control bread and bread with $10 \%$ substitution level (local lal) was moderately acceptable and other products (including 15\% substitution) were ranked as like slightly.
\end{abstract}

Keywords: Sweet potato flour, Sweet potato powder, Breads, Baked products

\section{Introduction}

Sweet potato belongs to the family Convolvulaceae and is one of the most important food crops in the world. As a world crop, it ranks seventh from the view point of total production after wheat, rice, maize, potato, barley and cassava (Zuraida, 2003). The annual world production of sweet potato was 105.1 million tons (Mt) in 2011. China is the largest grower of sweet potatoes, providing about $70 \%$ of the world's supply (FAOSTAT, 2011).

Sweet potato is rich in carbohydrate, dietary fiber, B-carotene, ascorbic acid, folic acid and minerals (Bovell-Benjamin, 2007; ILSI, 2008). Therefore, sweet potato is now widely used as an important human diet around the world.

Processing of sweet potato flour offers some great facilities such as: facilitating storage and transport; reducing bulkiness and losses due to high perishability of fresh sweet potato; increasing shelf life and improving nutritive value due to the fact that as a great part of the water content is removed, the carbohydrates, proteins, fat and minerals are concentrated in the tissues of dried food products. It also offers the facilities of creating new income opportunities for farmers such as new markets and new sources of income; changing some of the negative attitudes about sweet potato consumption, and enabling them to be an important commercial crop with a wide range of uses (Truong \& Ramesh, 2010).

Generally, breads are prepared from wheat flour but small amount of other cereal flours can also be used to give better nutritional value, special flavor or structural properties. Hagenimana et al. (1992) reported that addition of orange-fleshed sweet potato flour in chapattis and bans greatly increase the total carotenoids content. Various proportion of sweet potato flour can be used with wheat flour to improve nutritive values in terms of fiber and carotenoids. It can also be used to lower the gluten level that can causes coeliac disease (Tilman et al., 2003).

Today, people are more conscious about their foods. They always find foods that are convenient with great taste, reasonable price and carry important nutritional value. So, breads prepared using sweet potato flour can be a great choice because of its ready-to-eat nature, good nutritional value and low cost (Anonymous, 2006).

Considering the above factors, the present study has been undertaken with the following objectives:

(i) To analyze the compositions of fresh sweet potato and sweet potato flour.

(ii) To develop sweet potato flour substituted breads and assess the overall acceptability of the processed products. 


\section{Materials and Methods}

The experiment was performed in the laboratory of the Department of Food Technology and Rural Industries, Bangladesh Agricultural University, Mymensingh. The materials used in this study such as, drying trays, polythene bags, chemical solvents, distilled water were provided by the Food Technology laboratory. Wheat flour, sugar, salt, dalda, yeast (active dry yeast) and other ingredients were collected from the local market.

\section{Proximate analysis}

Proximate chemical composition represents the gross content of important chemical constituents such as moisture, protein, fat, carbohydrate, vitamin-C, specific minerals and ash.

\section{Moisture content}

The moisture content of the fresh and dried samples were determined in accordance to moisture measurement method for sweet potato AOAC (2000) method.

\section{Ash Content}

Total ash content was determined according to AOAC (2000) method.

\section{Fat content}

AOAC method (2005) was used to determine crude fat content of the samples.

\section{Protein content}

Protein was determined using AOAC (2005) method.

\section{Total carbohydrate}

Carbohydrate content of the samples was determined as total carbohydrate by difference that is by subtracting the measured protein, fat, ash and moisture from 100 (Pearsion, 1970). Total carbohydrate content of foods has, for many years, been calculated by difference, rather than analyzed directly.

\section{Preparation of sweet potato flour}

The fresh sweet potatoes were collected from local market. Then, they were processed to remove dirt and other field damaged portion. Cleaned sweet potato were chopped into small pieces with knife and dried at $65^{\circ} \mathrm{C}$ for about 16 hours using cabinet dryer. After cooling to room temperature, the dried sweet potatoes were ground into flour in a grinder. Then they were sieved and packaged in polythene bags and stored at room temperature for further use in the preparation of bread.

\section{Formulation of sweet potato bread}

The formulation of breads from local sada and local lal sweet potato flour are given in Table 1.

\section{Procedure for preparation of bread}

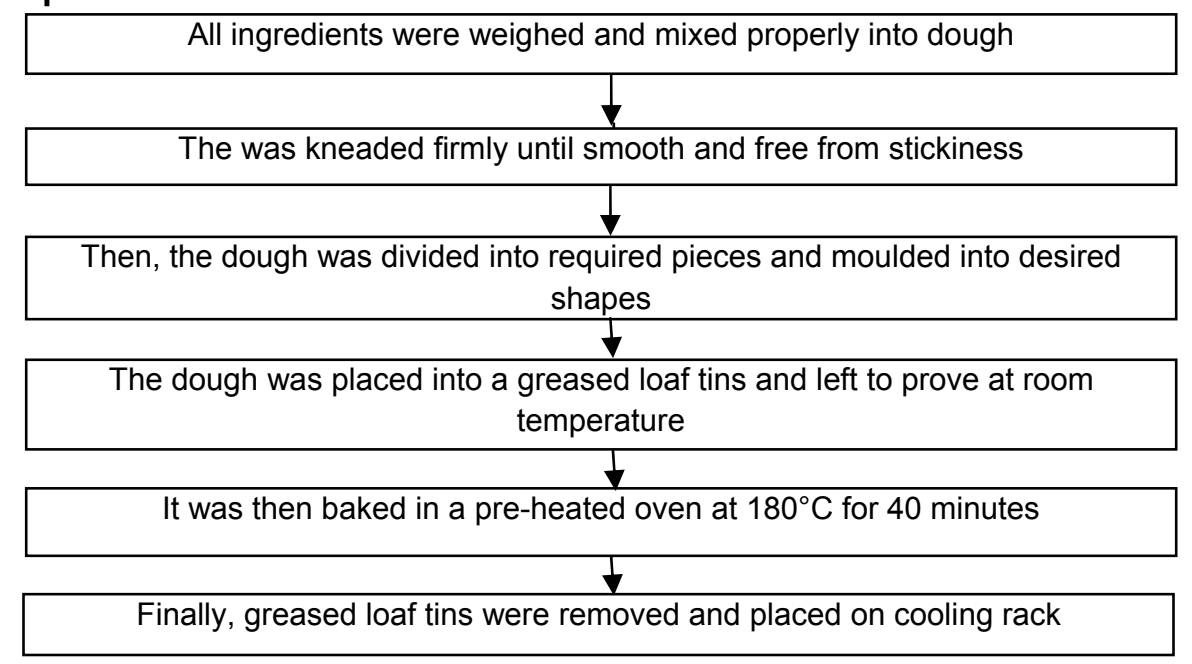

Fig. 1. Flow chart for preparation of bread from sweet potato 
Table 1. The formulation of breads from local sada and local lal sweet potato flour

\begin{tabular}{|c|c|c|c|c|c|c|c|}
\hline \multirow{2}{*}{ Ingredients } & \multicolumn{9}{c|}{ Sample Code } \\
\cline { 2 - 8 } & 401 & 402 & 403 & 301 & 302 & 303 & 555 \\
\hline Sweet potato flour (g) & 5 & 10 & 15 & 5 & 10 & 15 & 0 \\
\hline Wheat flour (g) & 95 & 90 & 85 & 95 & 90 & 85 & 100 \\
\hline Dry yeast (g) & 2.5 & 2.5 & 2.5 & 2.5 & 2.5 & 2.5 & 2.5 \\
\hline Sugar (g) & 5 & 5 & 5 & 5 & 5 & 5 & 5 \\
\hline Salt (g) & 2 & 2 & 2 & 2 & 2 & 2 & 2 \\
\hline Dalda (g) & 5 & 5 & 5 & 5 & 5 & 5 & 5 \\
\hline Water (ml) & 70 & 70 & 70 & 70 & 70 & 70 & 70 \\
\hline
\end{tabular}

[Here, $555=$ Control bread, 401= Bread with $5 \%$ local sada sweet potato flour, $402=$ Bread with $10 \%$ local sada sweet potato flour, $403=$ Bread with $15 \%$ local sada sweet potato flour, $301=$ Bread with $5 \%$ local lal sweet potato flour, 302 = Bread with 10\% local lal sweet potato flour, $303=$ Bread with $15 \%$ local lal sweet potato flour]

\section{Results and Discussion}

\section{Proximate composition of sweet potato}

Proximate composition of local sada and local lal sweet potato varieties are shown in the Table 2.

Table 2. Comparison of composition between fresh local sada and local lal sweet potato varieties

\begin{tabular}{|c|c|c|c|c|}
\hline \multirow{2}{*}{ Components } & \multicolumn{2}{|c|}{ Local Sada Variety } & \multicolumn{2}{c|}{ Local Lal Variety } \\
\cline { 2 - 5 } & $\mathrm{wb}$ & $\mathrm{db}$ & $\mathrm{db}$ & 201.02 \\
\hline Moisture Content (\%) & 70.10 & 234.45 & 66.78 & 12.67 \\
\hline Ash (\%) & 4.46 & 2.92 & 0.21 & 2.23 \\
\hline Fat (\%) & 0.71 & 5.85 & 1.63 & 4.91 \\
\hline Protein (\%) & 1.75 & 76.86 & 26.64 & 80.31 \\
\hline Carbohydrate (\%) & 22.98 & 29.63 & 9.49 & 28.57 \\
\hline Vitamin-C (mg/100g) & 8.86 & \multicolumn{2}{c|}{119.74} \\
\hline Energy (kcal) & \multicolumn{2}{|c|}{105.31} & \\
\hline
\end{tabular}

\section{Moisture}

The moisture content of local sada and local lal sweet potato varieties are shown in Table 2. From table, it is shown that local sada fresh sweet potato contains $70.10 \%(\mathrm{wb})$ and local lal fresh sweet potato contains $66.78 \%(\mathrm{wb})$ moisture content. This value is lower than Wenkam (1983) who indicated that fresh sweet potato had a moisture content of $87.8 \%(\mathrm{wb})$. The variation in moisture content of sweet potato might be due to varietal effects, stage of maturity, gaps between harvesting time and analysis etc.

\section{Ash}

In this study ash content in fresh sample was found to be as high as $4.46 \%$ and $4.21 \%$ in local sada and local lal fresh sweet potato respectively. But Goodbody (1984) reported the total ash content in fresh sweet potato as $1.7 \%$. This variation might be due to the varietal effect because different varieties contain different mineral matters.

\section{Fat}

The study showed that the fat content was $0.71 \%$ and $0.74 \%$ in local sada and local lal varieties respectively and the results were nearly similar to that obtained by Paul and Southgate (1979) who revealed that the fat content in fresh sweet potato was $0.61 \%$. This variation might be due to varietal effects.

\section{Protein}

As presented in Table 2, the protein content was $1.75 \%$ and $1.63 \%$ in local sada and local lal fresh sweet potatoes respectively. But Villareall et al. (1979) indicated that protein content in fresh sweet potato was $2.8 \%$. 


\section{Total carbohydrate}

This study showed that carbohydrate content of local sada and local lal sweet potato varieties were 22.98 and $26.64 \%$ respectively. These values were nearly similar to the value reported by Villareall et al. (1979) who quoted that fresh sweet potato contained $27 \%$ of carbohydrates.

\section{Vitamin C}

The vitamin C contents of sweet potato were $8.86 \mathrm{mg} / 100 \mathrm{~g}$ in local sada variety and $9.49 \mathrm{mg} / 100 \mathrm{~g}$ in local lal variety. But Wenkam (1983) quoted that, the fresh sweet potato contains vitamin C of $12.86 \mathrm{mg} / 100 \mathrm{~g}$. But on drying, these were reduced from $8.86 \mathrm{mg} / 100 \mathrm{~g}$ to $2.45 \mathrm{mg} / 100 \mathrm{~g}$ and $9.49 \mathrm{mg} / 100 \mathrm{~g}$ and 2.31 $\mathrm{mg} / 100 \mathrm{~g}$ in local sada and local lal varieties respectively. The losses observed in analysis result from peeling, cutting, soaking and drying because Vitamin $C$ is heat sensitive and water soluble.

\section{Energy}

Bovell-Benjamin (2007) quoted that sweet potato contained $116.25 \mathrm{kcal}$ of energy and Teow et al. (2007) indicated that sweet potato contain energy of $135 \mathrm{kcal}$. In this study the calculated energy was 105.31 $\mathrm{kcal}$ and $119.74 \mathrm{kcal}$ for local sada variety and local lal variety respectively. These values are nearly similar to the value calculated by Bovell-Benjamin (2007). The energy was determined by adding the results of multiplying fat content by 9 and carbohydrate and protein content by 4 .

\section{Compositions of sweet potato flour}

Table 3 shows that there is profound difference between the compositions of fresh sample and flour. From table, the protein content is as high as 10.34 and $9.21 \%(\mathrm{db})$ for local sada and local lal variety respectively. This is because the sweet potato used for preparing flour was freshly harvested (collected directly from field) and moisture content was higher than (almost $80 \%$ ) the fresh sample previously analyzed (cf Table 3). Table also shows that sweet potato flour contains fat content of 0.79 and $0.85 \%$ $(\mathrm{db})$, ash content of 4.35 and $4.40 \%(\mathrm{db})$, vitamin-c content of 2.59 and $2.44 \mathrm{mg} / 100 \mathrm{~g}$ for local sada and local lal variety respectively. This seems reasonable as protein is not destroyed at low temperature $\left(60^{\circ}\right.$ C). Okos et al. (1992) observed that protein loss during drying was a major nutritional problem. Roy (2012) also observed no loss in protein during drying of corn. Fat content and vitamin-C content were somewhat affected by among others oxidation and heat (Villatal and Hawkes, 1992).

Table 3. Compositions of sweet potato flour

\begin{tabular}{|c|c|c|c|c|}
\hline \multirow{2}{*}{ Components } & \multicolumn{2}{|c|}{ Local Sada Variety } & \multicolumn{2}{c|}{ Local Lal Variety } \\
\cline { 2 - 5 } & $\mathrm{wb}$ & $\mathrm{db}$ & $\mathrm{wb}$ & $\mathrm{db}$ \\
\hline Moisture Content (\%) & 5.25 & 5.54 & 5.32 & 5.62 \\
\hline Ash (\%) & 4.12 & 4.35 & 4.17 & 4.40 \\
\hline Fat (\%) & 0.75 & 0.79 & 0.81 & 0.85 \\
\hline Protein (\%) & 9.80 & 10.34 & 9.21 & 9.73 \\
\hline Carbohydrate (\%) & 80.08 & 78.98 & 80.49 & 79.4 \\
\hline Vitamin-C (mg/100g) & 2.45 & 2.59 & 2.31 & 2.44 \\
\hline
\end{tabular}

\section{Sensory evaluation of bread}

Seven samples of composite bread and the control were served to 10 panelists who were familiar with the sensory attributes- color, flavor, texture and overall acceptability of the samples. A nine point hedonic scale was designed to measure the degree of preference of the samples.

A two way of analysis of variance (ANOVA) (Table 4) was carried out for color preference and the result showed that, there was no significant difference in color acceptability of sweet potato bread. The score for color of sweet potato bread range from 6.85 to 7.43 . The highest score has been recorded for the bread containing $5 \%$ local sada sweet potato flour and $95 \%$ wheat flour. This means that this sample was ranked as like moderately. 
Table 4. Mean score for color, flavor, texture and overall acceptability of various sweet potato breads

\begin{tabular}{|c|c|c|c|c|c|c|c|}
\hline Sensory & \multicolumn{7}{|c|}{ Sample code } \\
\cline { 2 - 8 } Attributes & 401 & 402 & 403 & 301 & 302 & 303 & 555 \\
\hline Color & $7.43^{\mathrm{a}}$ & $7.14^{\mathrm{a}}$ & $7.29^{\mathrm{a}}$ & $7.27^{\mathrm{a}}$ & $6.85^{\mathrm{a}}$ & $7.28^{\mathrm{a}}$ & $7.28^{\mathrm{a}}$ \\
\hline Flavor & $7.00^{\mathrm{a}}$ & $7.00^{\mathrm{a}}$ & $6.71^{\mathrm{a}}$ & $7.00^{\mathrm{a}}$ & $7.00^{\mathrm{a}}$ & $6.71^{\mathrm{a}}$ & $6.85^{\mathrm{a}}$ \\
\hline Texture & $7.43^{\mathrm{a}}$ & $6.86^{\mathrm{ab}}$ & $6.43^{\mathrm{b}}$ & $6.86^{\mathrm{ab}}$ & $7.14^{\mathrm{ab}}$ & $6.71^{\mathrm{ab}}$ & $6.71^{\mathrm{ab}}$ \\
\hline $\begin{array}{c}\text { Overall } \\
\text { acceptability }\end{array}$ & $6.86^{\mathrm{a}}$ & $7.14^{\mathrm{a}}$ & $7.00^{\mathrm{a}}$ & $7.29^{\mathrm{a}}$ & $7.43^{\mathrm{a}}$ & $7.14^{\mathrm{a}}$ & $7.00^{\mathrm{a}}$ \\
\hline
\end{tabular}

[Here, $555=$ Control bread, 401= Bread with $5 \%$ local sada sweet potato flour, $402=$ Bread with $10 \%$ local sada sweet potato flour, $403=$ Bread with $15 \%$ local sada sweet potato flour, 301= Bread with $5 \%$ local lal sweet potato flour, $302=$ Bread with $10 \%$ local lal sweet potato flour, $303=$ Bread with $15 \%$ local lal sweet potato flour]

A two-way analysis of variance (ANOVA) (Table 4) for flavor of sweet potato bread was carried out and the result showed that, there was no significant flavor difference among sweet potato breads. From table 4.4, it was found that, samples 401, 402, 301 and 302 secured same score (highest score) and samples 403 and 303 secured lowest score. So, it is clear that all samples were statistically equal.

The score for texture of samples ranged from 6.43 to 7.43 (Table 4) with the highest score (7.43) obtained by the $5 \%$ local sada sweet potato bread (401) and lowest in the bread of $15 \%$ substitution of local sada sweet potato flour with wheat flour (403) and except 403, all other samples are equally acceptable. The table also showed that the control sample secured $6^{\text {th }}$ position in case of texture.

The scores for the overall acceptability (Table 4) of the prepared sweet potato breads were comparable to those of $100 \%$ wheat bread and ranged from 6.86 to 7.43 and all the products were equally acceptable. On the basis of overall acceptability, score sample 302 (contains $90 \%$ wheat flour and $10 \%$ local lal sweet potato flour) may be termed as moderately acceptable. It should however be stated that all products are equally accepted with ranking from like moderately to like slightly.

\section{Conclusion}

Different experiments under this study were carried out in the laboratory of the Department of Food Technology and Rural Industries, Bangladesh Agricultural University, Mymensingh. This study was conducted to analyze the proximate compositions of fresh sweet potato and sweet potato flour. After collecting the fresh sample, the proximate compositions were found to be $70.10 \%$ and $66.78 \% ; 1.75 \%$ and $1.63 \% ; 0.71 \%$ and $0.74 \% ; 4.46 \%$ and $4.21 \%$; and $22.98 \%$ and $26.64 \%$ of moisture, protein, fat, ash, and total carbohydrate on wet weight basis for local sada and local lal sweet potato varieties respectively. The proximate compositions of sweet potato flour were also analyzed and found profound difference between fresh and sweet potato flour.

Sweet potato flour can be used as alternatives to wheat flour for the preparation of a number of food products. It is generally used in foods to improve the textural properties and enhance the nutritional values. Processing technologies for producing sweet potato flour at large scale operation has been developed in many countries. With regard to the dehydrated forms, selection of sweet potato varieties with high levels of dry matter and phytonutrients should go hand in hand and by adopting technological improvements to reduce processing cost. It has been observed that substitution of $5 \%, 10 \%$ and $15 \%$ wheat flour by sweet potato flour has a positive effect on flavor, color, texture and overall acceptability of bread.

\section{Acknowledgements}

The author desires to express his thanks to NST authority as the research was supported by a research fellowship from NST (National Science and Technology), Ministry of Science and Technology, Government of the People's Republic of Bangladesh. 


\section{References}

Anonymous. 2006. Approved Methods of American Association of Cereal Chemists. The Am. Assoc. Cereal Chem. Inc., St. Paul. Minnesota.

AOAC. 2000. Official Methods of Analysis of the Association of official Analytical Chemist. 17th Ed. Washington D.C.

AOAC. 2005. Official Methods of Analysis of the Association of Official Analytical Chemist. 18th Ed. Washington D.C.

Bovell-Benjamin, A.C. 2007. Sweet potato: A review of its past, present, and future role in human nutrition. Advances in Food and Nutrition Research, 52, 1- 48.

FAOSTAT. 2011. Agricultural data. Rome, Italy: Food and Agriculture Organization of the United Nations. Available from: http://faostat.fao.org/site/408/DesktopDefault.aspx?PagelD = 408

Goodbody, S. 1984. Nutritional characteristics of a sweet potato collection in the Papua New Guinea highlands. Trop. Agric. (Trin.) 61:20-24.

Hagenimana, V., Carey, E., Gichuki, S.T., Oyunga, M.A., Imungi, J.K. 1992. Changes in carotenoid content after drying and processing sweet potato products. Ecological Food Nutrition. 37: 450-473.

ILSI (International. Life Sciences Institute). 2008. Nutritionally improved sweet potato. Washington, D.C.: IntI. Life Sciences Inst. Available at: (http://www3.interscience.wiley.com/cgi-bin/fulltext/119423793/PDFSTART). Access September 01, 2008.

Okos, M.R., Narsimhan, G., Singh, R.K. and Weitnauer, A.C. 1992. Food Dehydration in Handbook of Food Engineering. Edited by Heldman D. R. and Lund D. B. Marcel Dekker Inc.

Paul, A.A. and Southgate, D.A.T. 1979. McCance and Widdowson's the Composition of Foods, London, Her Majesty's Stationery Office. $417 \mathrm{p}$.

Pearson, D. 1970. The Chemical Analysis of Foods. 7th Edition. Churchill Livingstone, Newyork.

Roy, J. 2012. Kinetics of Sun and Mechanical Drying and Product Development Studies of Corn. M. S. Thesis. Department of Food Technology and Rural Industries, Bangladesh Agricultural University, Mymensingh. p-46.

Teow, C.C., Truong, V.-D., McFeeters, R.F., Thompson, R.L. Pecota, K.V. and Yencho, G.C. 2007. Antioxidant activities, phenolic and $\beta$-carotene contents of sweet potato genotypes with varying flesh colors. Food Chemistry, 103, 829-838.

Tilman, J.C., Colm, M.O.B., Denise, M.C., Anja D. and Elke, K. A. 2003. Influence of gluten free flour mixes and fat powder on the quality of gluten free biscuits. Eur. Food Res. Technol. 216: 369-376.

Truong, V.D. and Ramesh, Y. 2010. Sweet Potato Purees and Dehydrated Powders for Functional Food Ingredients. USDA-ARS Food Science Research Unit, Department of Food, Bioprocessing and Nutrition Sciences, North Carolina State University, Raleigh, NC 27695-7624, USA.

Villareal, R.L., Tsou, S.C.S., Lin, S.K. and Chiu, S.C. 1979. Use of sweet potato leaf tips as vegetables. II. Evaluation of yield and nutritive quality. Exp. Agric. 15:117-122.

Villatal and Hawkes. 1992. Kinetics in Food System, Handbook of Food Engineering. Edited by Dennis R. Heldman and Daryl B. Lund. Marcel Dekker, Inc.

Wenkam, N.S. 1983. Foods of Hawaii and the Pacific Basin Volume I: Composition, Hawaii Institute of Tropical Agriculture and Human Resources, University of Hawaii at Manoa, Research Extension Series 038. 172 p.

Zuraida, N. 2003. Sweet potato as an alternative food supplement during rice storage. J. Lubang Pertanian. 22(4):150-155. 